\title{
RECENSIES
}

\section{DE SYNTHESE VAN EEN ANALYTISCHE RICHTING.}

\section{Jan Woleniski: Logic and Philosophy in the Lvov-Warsaw School, Dordrecht/} Boston/London, (Synthese Library, volume 198) Kluwer, 1989, 378 blz., hfl. 195,ISBN $902772749 \mathrm{X}$

Wellicht is de naam 'school van Lvov-Warsaw' weinigen bekend. Wie kent echter niet de namen van Alfred Tarski, Jan Lukasiewics, Tadeusz Kotarbiński en Stańislav Leśniewski ? En dit zijn nog maar enkele namen van boegbeelden die in het eerste hoofdstuk van dit boek worden verbonden met het gemeenschappelijke vlaggeschip 'de school van Lvov-Warsaw'. In dit hoofdstuk geeft de auteur een historische schets van het ontstaan (einde negentiende eeuw), de bloeitijd (het interbellum) en het vergaan van de school (in de diaspora na WO II). De lezer wordt van in den beginne gewaarschuwd voor een al te overijlde vergelijking met de 'Wiener Kreis'. De zogenaamde 'Poolse school' is niet zomaar een variant van het logisch positivisme. (De verhouding tussen beide 'scholen' is het onderwerp van een andere recente publicatie bij dezelfde uitgever: The Vienna Circle and the Lvov-Warsaw School, Ed. by KI. Szaniawski, Dordrecht/Boston/London, Kluwer, 1988.)

Een portretgallerij vormt de overgang naar hoofdstuk twee. Hierin wordt een aantal facetten belicht van het filosofische denken van de stichter van de school, Kazimierz Twardowki. Dit overzicht is echter te summier om de invloed van Franz Brentano, leermeester van Twardowski, ten volle in het voetlicht te kunnen werpen. De lezer krijgt het gevoel dat de naam van Brentano blijkbaar belangrijker is dan zijn ideeèn. Bovendien blijkt dat de verdienste van Twardowski minder ligt in zijn 'philosophical views' dan wel in het feit dat hij de stichter is geweest van de Poolse school. De auteur getroost zich wel heel wat moeite om deze foute bewering te weerleggen. Of hij hierin slaagt is ten zeerste de vraag. Volgende passage is veelbetekenend " $\mathrm{Na}$ alles zou het moeilijk zijn zich een stichter van een wetenschappelijke school voor te stellen die als onderzoeker slechts middelmatig is" (blz.53) en illustreert bovendien de gebrekkige taalkennis van de auteur.

Het derde hoofdstuk toont aan hoe de gemeenschappelijke filosofie-conceptie in de school van formele aard is. Inhoudelijk is de samenhang binnen de school minder evident. In het vierde hoofdstuk (de ontwikkeling van de logica in de school) wordt de vraag gesteld naar het succes van de school. De rol van een aantal mystificaties rond kopstukken van de school wordt weliswaar gerelativeerd, maar ondertussen uitvoerig behandeld.Vanaf hoofdstuk vijf wordt het boek heel wat technischer. Zijn vorige hoofdstukken eerder historisch, dan volgt nu een meer systematische behandeling van een aantal disciplines waarin de Poolse school zeer actief is geweest. Op de eerste plaats de geformaliseerde logica met in hoofdstuk vijf een kort overzicht van de realisaties in het domein van de tweewaardige propositielogica (de fameuze 'Poolse notatie', de zoektocht naar zo sober mogelijke axiomatische systemen, de metalogica). In hoofdstuk zes komen de niet klassieke logica's aan bod. De meerwaardige en modale logica's 
danken hun ontstaan aan de filosofische interesses van de logici van de school. De discursieve logica van Jaśkowski is een voorloper in het onderzoek naar paraconsistente logica's.

Leśniewski (aan hem is het zevende hoofdstuk gewijd) is een buitenbeentje in de selecte club van logici. Volgens de auteur heeft dit alles te maken met het feit dat Leśniewki's logisch systeem (hierarchisch opgebouwd uit een 'Protothetic', een 'ontology' en een 'mereology') geen ingang heeft gevonden als logisch standaardsysteem (in tegenstelling tot de logische systemen van Russell en Lewis bijvoorbeeld) en heeft dit niets te maken met de intrinsieke waarde van de zogenaamde 'Leśniewski's Systems'.

Hoofdstuk acht is volledig gewijd aan Tarski en biedt een overzicht van een aantal bekende thema's uit diens omvangrijke en bekende oeuvre: de notie van een deductief systeem, de algebra van deductieve systemen en uiteraard de semantische waarheidstheorie. (Waarom ontsiert Wolenski ook hier de kritische evaluatie met niet ter zake citaten (blz.180) ook al zijn die van Russell en Popper? Goede waar prijst toch zichzelf ?)

Dat de Poolse school heel wat studiewerk heeft verricht in het domein van de logica-geschiedenis wordt uitvoerig uiteen gezet in hoofdstuk negen. De kritiek van Lukasiewicz op de aristotelische syllogistiek en de herwaardering van de stoïcijnse en Middeleeuwse logica zijn in het Westen genoegzaam bekend.

Hoofdstuk tien schetst de ontwikkeling in de epistemologie van Ajdukiewics, gaande van extreem conventionalisme (zonder ontologie) naar extreem empiricisme. In de bespreking van de reïstische ontologie van Kotarbiński (hoofdstuk elf) valt weerom de gelijkenis op met de 'Wiener Kreis'. De positivistische ontologie wordt opgevat als medicijn tegen speculatief denken en bepaalt de semantiek. Uit de taalfilosofie van de Poolse school heeft de auteur enkele thema's geselecteerd; zo onder meer de problemen omtrent analytische oordelen en lege namen.

Aan de wetenschapsfilosofie van de school is het voorlaatste hoofdstuk gewijd met daarin een aantal klassieke thema's zoals de redenering, inductie, waarschijnlijkheid en justificatie.

Een laatste hoofdstuk heeft het over de relatie van de Poolse school met het logisch empirisme, over de eenheid van de school en de plaats van de school in de geschiedenis van de wijsbegeerte. Voor de lezer die niet zo vertrouwd is met de filosofie van de Poolse school moeten vorige hoofdstukken eerder teleurstellen. De opstapeling van informatie, de historische én systematische opbouw van het boek, het soms storende chauvinisme van de auteur en bovenal het erbarmelijk Engels van de auteur maken het boek zeer moeilijk verteerbaar. Wie dan veel verwacht van een synthese en een vergelijking met de in het Westen beter bekende 'Wiener Kreis' komt bedrogen uit. De auteur is er in het laatste hoofdstuk niet in geslaagd beide 'scholen' historisch te plaatsen en beperkt zich tot het aangeven van een aantal verschilpunten die bij nader toezicht kleiner lijken te zijn dan de divergenties binnen de Poolse school zelf.

De auteur heeft het op blz.294 over "De onwil van de filosofen van de LvovWarsaw school om synthesen te formuleren". De vraag is of deze zogenaamde onwil niet gerechtvaardigd is. Het wezen van het analytische denken bestaat precies in een grondige afkeer van syntheses. Het analytische materiaal leent zich dan ook niet makkelijk tot synthese. Dit boek is hiervan een duidelijke illustratie. Daarom lijkt het ook gedoemd om als 'naslagwerk' (het boek bevat een zeer uitvoerige bibliografie) een uitermate rustig bestaan te kennen op de boekenplanken van enkele filosofiebibliotheken. 